\title{
Saving the Environment: Environmental Lessons in Colin Thiele's February Dragon
}

\author{
Burhanuddin Arafah \\ English Department, Faculty of Cultural Sciences, Hasanuddin University, Makassar, Indonesia \\ Herawaty Abbas \\ English Department, Faculty of Cultural Sciences, Hasanuddin University, Makassar, Indonesia
}

\author{
Nurul Hikmah \\ English Language Studies, Postgraduate Program, Faculty of Cultural Sciences, Hasanuddin University, Makassar, \\ Indonesia
}

\begin{abstract}
This article explores the relationship between humans and nature in February Dragon and elaborates on the environmental lessons conveyed in Colin Thiele's February Dragon. This article utilizes the concept of ecocriticism by Glotfelty. Ecocriticism explains human-nature interconnectedness. The portrayal of human-nature relation reveals several values of environmental education that readers, both children, and adults, could learn. Three environmental lessons such as respect, responsibility, and empathy towards other living beings were found in the story. Based on the elaborations, the characters in the novel show their respect, responsibility, and empathy towards other species by protecting the animal and the environment from bushfire's dangers.
\end{abstract}

Index Terms-human and nature, February Dragon, environmental lessons, ecocriticism

\section{INTRODUCTION}

People's intense activities have considerably changed the natural environment due to their intimate relationship to science and technology which can mainly be felt and seen in the era of the industrial revolution (Arafah, B. \& Hasyim, M., 2019). For instance, mobile cellphone now can be regarded as a basic need after a meal (Arafah, B. \& Kaharuddin, 2019). Despite the widely known fact that technology has offered a great deal of a more advanced lifestyle in several sectors (Arafah, B., 2021; Butarbutar et al., 2021; Farid et al., 2021), the dynamic change in technology has dramatically led to changes in the context of environmental constraints and opportunity (Suleman, D., 2021). It is widely recognized that the strong connection between people and technology (as the product of science development) has caused careless lifestyle that potentially accelerates the rise of environmental issues in this modern world e.g. air pollution, the climate crisis, deforestation, biodiversity loss, plastic pollution and many more (Kaharuddin, Ahmad, D, Mardiana, Rusni, 2020).

In Indonesia, deforestation and land clearing donate around 47.7 percent of total greenhouse gas emissions (Murti, 2019). As reported in climate.nasa.gov in March 2020, there are about 413 carbon dioxide components per million that are at their highest level in 650,000 years. Global temperature and sea level are influenced directly by this phenomenon. According to NASA, since the last nineteen centuries, our global temperature has increased by about 1.6 degrees Fahrenheit. The global average sea level has risen by almost $178 \mathrm{~mm}$ over the past hundred years. What we learn from the facts is that the environmental condition affects the life of society because all societies are an integral part of their environment (Hasjim, M., Arafah, B., Kaharuddin, Verlin, S, \& Genisa, R. A. A., 2020). In a nutshell, changes in the environment affect people and their society. When the environment is in danger, people are also in danger. On the other hand, as the environment is safe, people and their societies are safe as well (Arafah, B., Thayyib, M., Kaharuddin, \& Sahib, H., 2020).

In response to the environmental issues, a strong need is urgently required to encourage people's awareness of the environment. A technique concerning the education of the natural environment can be employed to meet this need (Andi, K., \& Arafah, B., 2017). The technique is essential since it shows a way of carrying out the task by implementing a scientific procedure (Ismail, Sunibi, A. H., Halidin, A., \& Amzah., Nanning., Kaharuddin., 2020). The technique is aimed at giving knowledge or perception of the environment situation, which is eventually able to affect their skills and actions to preserve and protect the natural environment in their daily lives (Erdoğan, M., Coşkun, E., \& Uşak, M., 2011, Arafah, B., \& Kaharuddin, 2019). Hence, there must be a decisive action to educate people regarding their environments as an integral part of their societies. This decisive action is also well-known as environmental education. Environmental education should not be simply provided as a subject in scientific disciplines (Tilbury, D., 1995). The works of art, literature, and other disciplines of humanities should also take apart to encourage individuals' 
responsibility for the natural environment through the use of existing motifs, themes, and values available in such works (Hasyim, M., Arafah, B., \& Kuswarini, 2020).

Many things can be used as lessons in protecting the environment for human survival. One of them is a literary work, which has many benefits to the reader's life since the literary works are generally a reflection of the life at one period. Therefore, literary works are called the result of social products that have many life benefits... everyone must learn from anything and anyone including animals because whatever happens in the universe is a teacher (Irmawati \& Arafah, 2020).

Art and literature can be employed as reliable instruments to foster environmental responsibility and awareness among individuals (Özdemir, O., 2006, Arafah, B. \& Kaharuddin, 2019). Literature can be understood as a written piece of work containing aesthetic merits produced by authors (Arafah et al., 2021). In addition, Schneider-Mayerson (2020) believes that the general increase of understanding and concern has been echoed by artists and cultural creators, including novelists through their works. Fiction regarding climate change, or cli-fi, has attracted substantial media and critical interest. Starting in 1990, climate change in literature and literary studies is no longer a marginal topic and is being regarded as a specific subfield of literary studies, particularly in literary or critical theory (Johns-Putra, 2016). These days, literature and the environment have become popular topics among literary students. Although this kind of research is only done through textual analysis, it cannot be denied that what is written in literary work is the reflection of real life, as Abrams (1971) designates as "mimesis," art is the imitation of the universe. The imitation of nature reflected in literary works can usually be identified by describing shreds of evidence that the writers presented on pages, chapters, and parts of the novel (Purwaningsih \& Arafah, 2020).

Environmental fiction has several positive externalities that make them a fitting object for analysis. In the educational context, various authors have emphasized the importance of natural environments and the significance of other living beings (Babb, Janine, \& Miller, 2017). Schneider-Mayerson (2020) argues that climate fiction can play a hand in facilitating people to identify, appreciate, and feel the devastating course on which we find ourselves and map a better direction ahead. It can be concluded that researching environmental fiction will increase environmental awareness and help to find solutions to the ecological problems that are happening now.

Following the trend, children's environmental literature has flourished since the early 1990s (Echterling, 2016). Critics started to investigate children's environmental literature after environmental literary studies, or eco-critics began to gain attention in the early 1990s (Gaard, 2009). Various children's book publications regarding environmental issues commonly are found in developed countries like the USA, Australia, Scandinavian countries, Canada, Germany, France, and Italy (Gonen \& Guler, 2011)). Some of the notable publications are Wild Things: Children's Culture and Ecocriticism by Sidney I Dobrin and Kenneth B Kidd and Greta Gaard's “Children's Environmental Literature: From Ecocriticism to Ecopedagogy".

Children's literature includes books that cover topics related to children from birth until the age of adolescence, whether in prose or poetry, fiction, or non-fiction (Lynch-Brown \& Tomlinson, 2005). Literature brings new experiences for children and provides new information, explains issues that children are interested in, based on children's needs through their contents (Gonen \& Guler, 2011). Depiction towards characters displaying empathy, an animal or environment, and illustrations design to elicit can be highly influential on readers (Gaard, 2009). Platt (2004) states that "environmental justice children's literature provides "stories for children that examine how human rights and social justice issues are linked to ecological issues, how environmental degradation affects human communities, and how some human communities have long sustained symbolic relation with their earth habitats".

The purpose of this study is to explore the human-nature relationship based on character performance and elaborate on the environmental lessons conveyed in February Dragon, an Australian children's book written by Colin Thiele. The book is content analyzed by referring to the exploration of good values within which potentially encourage children's environmental knowledge, cognitive skills, as well as environmentally responsible behavior. Environmental lessons in children's literature are believed able to foster young people's environmental responsibility and awareness that they are expected able to productively engage with the challenges of environmental issues and relatively easy to take the physical type of action (i.e., waste management, saving water and electricity, planting, protecting animals and plants) in their real-life situations(Christenson, M. A. 2009).

\section{LITERATURE REVIEW}

\section{A. February Dragon: An Environmental Literacy}

February Dragon is an episodic story, which was commended by the Children's Australian Book Council in 1966, and was written at the request of the South Australian Bushfire Research Centre, hoping for a "harrowing tale" could do for the prevention of bushfires what Storm Boy had done to protect wildlife in the Coorong Wetlands at the mouth of the Murray River (Clark, 2010). Grey (1994) states that Thiele's novel focuses on for environment and preservation of wildlife during that period. Thiele's stories were pro-environmental and sympathetic to an animal long before either cause was fashionable. His work such as Storm Boy, Fire in the Stone, and February Dragon, represents environmental issues, especially in Australia.

This work specifically contains a story about the adventures of three Australian children, Resin, Turps, and Columbine, who lived on a remote farm in Australia surrounded by bushland. The novel took place in a fictional town 
called Gumbowie, which was located in a rural area of South Australia. The story told from a third-person point of view tells of the daily lives of the children of The Pine, Resin, Turps, and Columbine, who were full of enjoyable adventures before the raging bushfires destroyed the whole country.

February Dragon is likely inspired by the actual environmental issues that happened in Australia during the nineteenth century, the bushfires. The title February Dragon attributes to Australia's raging wildfire, which is often happened in February. Some of the worst fire happened during 19 century was Black Thursday happened on February 6, 1851, Red Thursday on February 1, 1898, Black Sunday on February 4, 1929, and many more arrival in the following years after (Rigby, 2015).

The portrayal of bush life in February Dragon is very realistic. Thiele vividly illustrates Australia's atmosphere during summer, especially in South Australia, which is described as dry and windy. The use of anthropomorphic imagery and zoomorphic imagery are also shown his concern for the environment. The story raises issues like deforestation, pollution, and animal oppression. The story told that there had been many land and animal exploitations for the sake of human needs. As a result, humans have to accept the consequence of their careless behavior.

It is undeniable that February Dragon contains numerous environmental lessons that will practically be a significant endeavor in promoting environmental awareness since the story told about how humans interact with nature and its impact on the environmental disaster. Moreover, it also shows the role of children's literature on climate change in raising young people's awareness about their responsibility to the biosphere.

\section{B. Ecocriticism and Children Literature}

Many ecocritics indicate Silent Spring (1962) by Rachel Carson as the first modern natural writing, while Peter Barry (Barry, 2017) and (Glotfelty, 1996) said that the term ecocriticism was possibly first mentioned in 1978 in William Rueckert's essay "Literature and Ecology". The establishment of ASLE (Association for The Study of Literature and Environment) in 1992 and its journal called ISLE (Interdisciplinary Studies in Literature and Environment) in 1993 were when ecological literary studies, known as ecocriticism, had become a famous critical school (Gaard, 2009 , p. 322). As environmentalism originated in the United States during the second half of the 20th century as a cohesive political movement, children's literature soon began to seriously represent its concerns (Echterling, 2016, p. 287).

Since it was coined, ecocriticism was based on the premise that text studies have a great influence on readers and the world in general (Mayerson et.al). In the introductory part of The Ecocriticism Reader: Landmarks in Literary Ecology, Glotfelty emphasizes the importance of literary studies in the age of environmental crisis. According to Glotfelty (1996, p. Xv), the study of literature in the twentieth century is still overlooked several aspects like gender and race but lack attention to the environmental aspect. Glotfelty proclaimed the concept of "ecocriticism" as a response to the global environmental crisis. She defines ecocriticism as "the study of the relationship between literature and physical environment" (Glotfelty, 1996).

In the field of children's literature, according to Gaard (2009), ecocriticism affiliated with children's literature started with the special publication of The Lion and The Unicorn on "Green Worlds: Nature and Ecology" in 1995 and on " Ecology and the Child" in the Children's Literature Association Quarterly in Winter 1994-1995 together with ISLE publication series of Dr. Seuss' The Lorax. A few years later, in 2004, the notable publication of Sid I. Dobrin and Kenneth B. Kidd's Wild Things: Children Culture and Ecocriticism marked as a formal way of children's environmental literature in becoming subject in the literary field.

In reading literature, including children's literature, Glotfelty (1996) proposes several questions that ecocritics could ask, including "Are the values expressed in this play consistent with ecological wisdom?" and "how do our metaphors of the land influence the way we treat it?" Those notions could be used as a basic understanding to explore human nature-relationship and elaborated environmental messages that the author conveyed in the novel.

On that note, O'Brien and Stoner (1987) argue that there are four basic understandings provided by environmental education. First, people and other wild species require the same basic needs. Second, the living and non-living elements are interdependent. Third, people influence the environment while the environment affects people. Lastly, people are responsible for their action's effect on the environment.

Based on the elaboration of ecocriticism and children's literature, it can be concluded that analyzing children's literature from the perspective of ecocriticism will reveal the ecological aspects contained in the story. By revealing those ecological aspects, the reader will find environmental wisdom that the author implies or explicitly written.

\section{FINDINGS AND DISCUSSIONS}

\section{A. Saving the Environment: Environmental Lessons in February Dragon}

Thiele's novel February Dragon (1966) is one of his exemplary works in representing his environmental stance on the relationship between man and nature. The title of the novel itself is a representation of Thiele's thoughts. Thiele uses the word "February" to refer to the hottest month during the summer in Australia and also to refer to the bushfire events in Australia that often occur in February. The word dragon is also another important word in the title. Dragon refers to a firestorm, which is the name taken from the mythical animal that breathes fire. Thiele chose February Dragon as his title to remind the reader of the most dangerous thing in Australia, The Bushfires. 
From the very outset, the novel breaks down the relationship between man and nature. In this case, all living and nonliving things are included. The relationship between humans and non-human has been vigorously debated. Religions and philosophers have different notions about human creation and human-nature relationships. Within Western Intellectual Tradition, the relationship between humans and nature is known as either dichotomous, human beings are separate and distinct from nature or hierarchical, human beings are part of nature. However, human positions are higher than other creatures (Sandler, 2012, p. 285).

The characters in the novel show two types of human nature relationships; superior or anthropocentric human beings are distinct from other entities, and equal, which means humans and other entities holding the same position on this planet. The anthropocentric aspects of human beings shown in the text consist of dominating and caretaking. Based on Thiele's illustration of the relationship between man and nature, there are two kinds of human position in the ecosphere, sometimes human sentimentalizing or dominating the environment, but they can also be the caretakers of the earth. Thiele also portrays the sense of equality in the relationship of human nature.

Dominating is portrayed by deforestation, animal racist, or speciesism, which later showing its impact at the end of the story. Deforestation is described in the early stages of the story when the migrants moved to the rural area after The War. The migrants cleared the land to build houses, farms, roads, telephone lines, and factories. For animal discrimination, it can be seen by how the characters treat the animal as their property, both domesticated and wild animals.

Although the novel in general shows how human behavior negatively influences environmental sustainability, the author, also illustrates the idea of caretaking. Thiele's stance regarding the caretaker position of human beings manifests in his characterizations of the children. Resin, Turps, and Columbine. The Pines children are the perfect example of stewardship. The children show their compassion and love towards animals reflected by how they treated all the domesticated animal animals on the farm and wild animals in the bush, which is elaborated in the following parts.

\section{B. Respect, Responsibility, and Empathy}

After elaborating human-nature relationship, there are three values that readers can learn based on the care-taking side of human beings, which are respect, responsibility, and empathy. In this regard, value refers to something worth which can be used as an individual's standard of behavior in life (Arafah, K., Arafah, A. N. B., \& Arafah, B., 2020).

\section{Respects}

O'Brien and Stoner (1987, p. 14) argue one of the basic understanding of environmental education is "People and wildlife have the same basic needs". This understanding will lead people to respect the environment, including animals and plants.

At the beginning of the story, Thiele illustrates Bottlebrush Barn, a shady house near the bush where Resin, Turps, and Columbine lived as a wonderful place for pets. There were three mongrel tomcats, three dogs, five calves, two lambs, thirteen piglets, half a dozen goats, two ferrets, a galah, and one possum resided in Bottlebrush Barn. There were also regular visitors, a kookaburra, and a goanna. Because they loved animals, the children decided to christen every pet and wild animal that was staying or visiting Bottlebrush Barn. Admittedly the calves were not house pets, so they christened each one and spoke it as part of the farmyard (Thiele, 1966, p. 12). This situation proves that the children respected the animal because both domesticated and wild animals in the bush were treated as a family by the children.

How the children show their respect for the environment, especially to the animals, can be seen from their kindness. Turps's relationship with ginger is one of the examples of a human and animal harmonious relationship. When Ginger arrived to the Barn, Turps confidently declared that they already know each other. "she kept saying "I'm your . . . your new mate (Thiele, 1966, p. 35). Turps also treated Ginger just like her family. Since Ginger came into the house, it became her priority.

They all laughed then and went into afternoon tea. All except Turps. She led Ginger back to the stable to brush her down. For Ginger came first — even before afternoon tea (Thiele, 1966, p. 40).

Turps's interaction with Ginger shows that humans and animals can be more than just humans and their property relationships. However, they can be a family and friend relationship.

\section{Responsibility}

People are accountable for their effect on the environment (O'Brien \& Stoner, 1987). By respecting the animal, humans will build their responsibility in protecting the environment. Thiele's idea of promoting environmental responsibility is expressed by the increasing awareness of the danger of bushfires.

Government and townspeople do their best to protect the land. The government, as mentioned in the novel, employs several rules to avoid the blazes. There is a total fire ban at some areas of the dry forest during the summer, both in the private and state-owned forest. Following the government's implementation, many citizens from different professions volunteer as E.F.S (Emergency Fire Service).

The E.F.S, which was the fire and emergency service that operated in rural areas of South Australia, was ordinary men from different professions who sacrificed their time and life every time they sounded. Men from farms, churches, and offices were gathered together $r$ to save the land from the raging bushfires.

Resin knew well enough what that meant he had seen the men of the Emergency Fire Service training at Upper Gumbowie. The members were ordinary men: shearers and wheat growers, truck drivers, clerks and shopkeepers from the farms and little towns, who dropped everything and rushed off in the fire trucks whenever an alarm sounded. They 
spread the news by telephone, wireless, and sirens until men came pouring toward the fire from every farm and township for miles round (Thiele, 1966, p. 17).

Every time the alarm sounded, the E.F.S would spread the news and sprightly ran to the fire location. These volunteers dedicated their lives to protect the land from the dangerous bushfires every single year.

Their close relationship with animals has built their empathy towards animals. It is illustrated by Thiele when the children rescued a baby possum hit by a car, which is later called Pinch. The children were crossing the road heading to the gate when they found a baby possum hit by a car on the road near Bottlebrush Barn. Without hesitating, they brought the possum to the house, feeding it patiently till it grows bigger, just like the average possum. For days they thought of nothing else, they fed it with milk from an eyedropper, a drip at a time. They wrapped it in an old woolen scarf and put it by the fire (Thiele, 1966, p. 42). The way Resin, Turps, and Columbine took care of the baby Possum shows their love and kindness towards other kinds without discriminating their species.

Thiele also shows the responsibility of humans in maintaining the sustainability of the environment through the attitude of the characters. Some characters in the novel have shown their thought against any action that could trigger a fire. It can be seen from the conversation between Mr. and Mrs. Pine one day at the veranda.

"People shouldn't be allowed to throw their cigarettes and matches out of passing cars. Don't they know there's a law against it?

"People are careless Muriel... They forget they're in the bush, and they just toss out their butts as though they are dating in St. Hilda Road over Sydney Harbor Bridge (Thiele, 1966, p. 17).

Through the dialogues above, Mr. Pine shows his troubled mind regarding human carelessness, which will damage the environment. People started to acknowledge that the situation was getting more devastating because the climate condition was getting worse. The same situation can be seen in Stravy and Lemmen when they caught the boys smoking in the bush. They warned the boys about the worst consequence of their careless action if they smoke during the summer.

Empathy

Understanding the existence of other living beings will build empathy inside human beings. In many parts of this novel, Thiele also shows how humans appreciate nature through the character's interaction with the environment. Thiele shows Mr. Pine when they drove home after having charismas lunch at Summertown.

"It's just as well," Mr. Pine said, slackening the belt on his old working trousers, "that Christmas comes only once a year. Otherwise, the people would all be dead from overeating, and the animals from starvation and neglect (Thiele, 1966, p. 115).

After having a family lunch at Summertown, Mr. Pine decided to return home earlier because he wanted to feed the animals on the farm (From the quotation above). There is some irony presented in Mr. Pine's thought about Christmas as he illustrated the comparison between humans, who get an enormous supply of food when animals starved to death because humans ignore them. Mr. Pine action represents human's empathy towards animals

The children also show their empathy when one of their loyal farm dogs, got a skin disease. It was Woppit, a kangaroo dog that had been guarding their father's farms for more than ten years. One day Woppit suffered from severe skin disease. The children felt bad for Woppit, so the children decide to tell their father to bring him to the Vet in Summertown. When their proposal to bring Woppit to the vet in Summertown was refused by Mr. Pine, the children tried to find alternatives by giving him a balm from the old Barnacle store.

\section{CONCLUSION}

Children's literature is vital because it gives readers an understanding of their own culture; it helps students develop emotional intelligence and creativity; it encourages and conveys important messages and themes. February Dragon is a perfect example of children's environmental fiction. Thiele unravels the interaction between humans and non-human and its impact. Moreover, Thiele also conveyed many environmental lessons to increase the awareness of his readers, especially children. This paper highlights three environmental lessons such as respect, responsibility, and empathy towards the environment that will be a good example in promoting environmental awareness for both children and adults.

\section{REFERENCES}

[1] Andi, K., \& Arafah, B. (2017). Using needs analysis to develop English teaching materials in initial speaking skills for Indonesian college students of English. The Turkish Online Journal of Design, Art, and Communication (TOJDAC), Special Edition, 419-436.

[2] Abrams, M.H. (1971). The Mirror and the Lamp: Romantic Theory and the Critical Tradition, London: Oxford University Press.

[3] Arafah, B. \& Hasyim, M. (2019). Linguistic functions of emoji in social media communication. Opcion. Vol. 35 (24), 558-574.

[4] Arafah, B., \& Kaharuddin. (2019). The Representation of Complaints in English and Indonesian Discourses. Opción, 35, 501517. 
[5] Arafah, B., Kaharuddin, Takwa, Arafah, Azhariah Nur B., Kadaruddin, Leba, Seli Marlina Raja. (2021). Promoting the Building up of Character Education Based on Literature, Culture, and Local Wisdom. Linguistica Antverpiensia, 2021 (1), 2129-2147.

[6] Arafah, B., Kaharuddin, Mulyanto, Arifin, M. Bahri, Rofiqah, Ummu, Arafah, Azhariah Nur B. (2021). The Idol: An Innovative Model for Designing Literature-Based Elt Materials. Linguistica Antverpiensia, 2021 (1), 2075-2090.

[7] Arafah, B. \& Kaharuddin (2019). The Idol: A Model for Incorporating Literature in ELT. KnE Social Sciences, 43-59.

[8] Arafah, K., Arafah, A. N. B., \& Arafah, B. (2020). Self-Concept and Self-Efficacy's Role in Achievement Motivation and Physics Learning Outcomes. Opción, 36, (27), 1607-1623.

[9] Arafah, B., Thayyib, M., Kaharuddin, \& Sahib, H. (2020). An anthropological linguistic study on Maccera' Bulung ritual, Opción, 36, (27), 1592-1606.

[10] Babb, Y.M., Janine, M. and Miller, K.K. (2017). 'Tracking the environment in Australian children's literature: the Children's Book Council of Australia Picture Book of the Year Awards 1955-2014', Environmental Education Research, vol. 24, no. 5, May, 716-730.

[11] Baharuddin, Andi Farid, Arafah, B., Ruing, Fentry Hernaningsi, Muaffaq, Ahmad, Nasrawati. (2021). Improving the Potential of English Language Skills for the Indonesian Learners through English Song. Linguistica Antverpiensia, 2021 (1), $2166-2182$.

[12] Barry, P. (2017). Beginning Theory: An Introduction to Literary and Cultural Theory, 4th edition, Manchester: Manchester University Press.

[13] Butarbutar, R., Arafah, B., Leba, Seli Marlina Raja, Kaharuddin, Sauhenda, Angla F., Monika, Santy (2021). Using MobileAssisted Language to Encourage EFL Learning among Indonesian Learners of English. Linguistica Antverpiensia, 2021 (2), $766-779$.

[14] Christenson, M. A. (2009). Children's Literature on Recycling: What Does it Contribute to Environmental Literacy. Applied Environmental Education \& Communication, 7(4), 144-154.

[15] Clark, N. (2010) Inhuman Nature: Sociable Life on a Dynamic Planet. London, United Kingdom: SAGE Publications Ltd.

[16] Echterling, C. (2016). 'How to Save the World and Other Lessons from Children's Environmental Literature', Child Lit Educ, vol. 47, December, 283-299.

[17] Erdoğan, M., Coşkun, E., \& Uşak, M. (2011). Developing children's environmental literacy through literature: An analysis of 100 basic literary works. Eğitim Araştırmalart-Eurasian Journal of Educational Research, (42), 45-62.

[18] Gaard, G. (2009). 'Children's Environmental Literature: From ecocriticism to ecopedagogy', Neohelicon, Volume 36, No 321, September, 321-334.

[19] Glotfelty, C. (1996). 'Introduction', in Glotfelty, C. and Fromm, H. (ed.). The Ecocriticism Reader: Landmarks in Literary Ecology, Athens: University of Georgia Press.

[20] Gonen, M. and Guler, T. (2011). 'The Environment and Its Place in Children's Picture Story Books', Procedia - Social and Behavioral Sciences, vol. 15, January, 3633-3639.

[21] Grey, S. (1994). 'Colin Thiele: Images, Issues, and Role Models', Orana, vol. 30, no. 1, 6-13.

[22] Hasjim, M., Arafah, B., Kaharuddin, Verlin, S, \& Genisa, R. A. A. (2020). Principles behind Semantic Relation between Common Abbreviations and their Expansions on Instagram. International Journal of Criminology and Sociology, (9), 22702276.

[23] Hasyim, M., Arafah, B., \& Kuswarini, P. (2020). The new Toraja destination: adding value Toraja coffee of the sustainable tourism development. IOP Conference Series: Earth and Environmental Science (Vol. 575, No. 1, 012072), IOP Publishing.

[24] Ismail, Sunubi, A. H., Halidin, A., \& Amzah., Nanning., Kaharuddin. (2020). Paraphrasing Technique to Develop Skill for English Writing Among Indonesian College Students of English. Systematic Reviews in Pharmacy, 11(11), 291-297.

[25] Irmawati, I., Arafah, B., \& Abbas, Herawaty. (2020). The Lesson Life of Santiago as Main Character in Coelho's The Alchemist. Jurnal Ilmu Budaya, Volume 8, Nomor 1, 2020, 32-36.

[26] Johns-Putra, A. (2016). 'Climate change in literature and literary studies: From CLI-fi, climate change theater and eco-poetry to ecocriticism and climate change criticism', Wiley Interdisciplinary Reviews: Climate Change, vol. 7, no. 2, 266-282.

[27] Kaharuddin, Ahmad, D, Mardiana, Rusni. (2020). Contributions of Technology, Culture, and Attitude to English Learning Motivation during Covid-19 Outbreaks. Systematic Reviews in Pharmacy, 11 (11), 76-84.

[28] Lynch-Brown, C. and Tomlinson, C.M. (2005). Essentials of Children's Literature, 5th edition, Boston: Pearson Education.

[29] Murti, F.N. (2019). 'Indonesia's green literature: 'the sleeping beauty' literary, IOP Conference Series: Earth and Environment Science, 243 (2019) 012165 IOP Publishing doi:10.1088/1755-1315/243/1/012165.

[30] NASA: Climate Change and Global Warming. (2020). [Online source] Available at: https://climate.nasa.gov/evidence [6 March 2020].

[31] Özdemir, O. (2006). The effects of literature on the sensibility towards the environment and its value in the environmental education system. Eurasian Journal of Educational Research, 23, 159-167.

[32] O'Brien, K. and Stoner, D.K. (1987). 'Increasing environmental awareness through children's literature, The Reading Teacher, vol. 41, no. 1, 14-19.

[33] Platt, K. (2004). 'Environmental justice's children literature: Depicting, defending, and celebrating trees and birds, colors and people', in K., K. (ed.) Wild Things: Children's culture and ecocriticism, Detroit: Wayne State University Press.

[34] Purwaningsih, Yuni Ratna, Arafah, Burhanuddin, Abbas, Herawaty. (2020). An ambition of infidelity "Emma Bovary" as wife: Sexuality problems. Medicina Clinica Practica, 3 (S1):100108, 1-3.

[35] Rigby, K. (2015). Dancing with Disaster: Environmental Histories, Narratives, and Ethics for Perilous Times. Charlottesville: University of Virginia Press.

[36] Sandler, R. (2012). Environmental Ethics, Overview, in Chadwick, R. (ed.) Encyclopedia of Applied Ethics (Second Edition). London, United Kingdom: Academic Press, 105-113.

[37] Suleman, D., Arafah, Burhanuddin, Abbas, Herawaty, and A, Delukman. (2021). Women Discrimination in Malaysia: Examining 'The Gender Agenda' from the Viewpoint of Lenore Manderson's Women, Politics, and Change. Linguistica Antverpiensia, 2021 (1), 2204-2222. 
[38] Tilbury, D. (1995). Environmental education for sustainability: Defining the new focus of environmental education in the 1990s. Environmental education research, 1(2), 195-212.

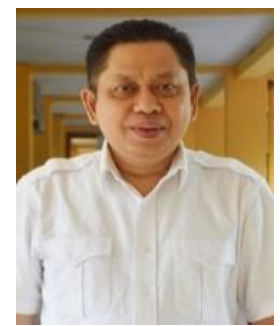

Burhanuddin Arafah obtained his Ph.D. degree in English (Australian) literature at the University of Newcastle Australia in 2003. He earned his Master's degree in American literature at Gadjah Mada University (UGM) Yogyakarta of Indonesia in 1995, and his Bachelor's degree in English literature at Hasanuddin University (UNHAS) in 1988.

$\mathrm{He}$ is currently a full Professor in English literature at the English Literature Study Program, Faculty of Cultural Sciences of Hasanuddin University (UNHAS) Indonesia. He has published 4 books in English language and literature and more than 50 research articles ranked international journals published in the English language. He also has received 24 Intellectual Property Right Certificates from the Indonesian government. His areas of interest are English literature, language education, and cultural studies, He was the Dean of the Faculty of Cultural Sciences of Hasanuddin University in 2009-2017, and currently, he is actively involved at the National Accreditation Board-Higher Education, Ministry of Education and Culture of the Republic of Indonesia for his position as Assessor.

Professor Arafah is currently a member of the Indonesian Literature Scholar Association, and Linguistics and Literature Association of Indonesia, as well as actively involved in the Indonesian Linguistics Society Association.

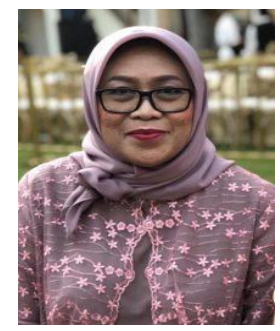

Herawaty Abbas got her Ph.D. at the University of Newcastle Australia in 2013, and her master's degrees in Gadjah Mada University (UGM) Yogyakarta of Indonesia in 1997 and Saint Mary's University Canada in 2001.

She is currently an Associate Professor at the English Literature Study Program, Faculty of Cultural Sciences of Hasanuddin University Indonesia. Her doctorate thesis examines the potential dialogue between Australian and Buginese culture in terms of feminism. Her research interests are in feminist literature, children's literature, and Indigenous literature. She has published some articles in reputable international journals, such as Women Discrimination in Malaysia: Examining 'The Gender Agenda' from the Viewpoint of Lenore Manderson's Women, Politics, and Change, published in Linguistica Antverpiensia, 2021 (1), 22042222; and The Values of Character Education in Pullman's The Golden Compass, published in Multicultural Education, Volume 7 , Issue $1,2021$.

Dr. Abbas is currently a member of the Indonesian Literature Scholar Association, and the Indonesian Linguistics Society Association.

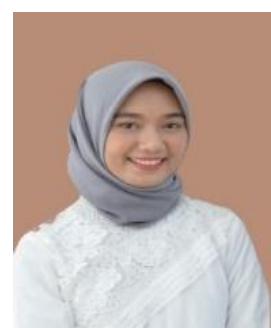

Nurul Hikmah obtained both her bachelor's and master's degrees in Hasanuddin University (UNHAS) Makassar of Indonesia. She completed her bachelor's degree in English Literature, Faculty of Cultural Sciences UNHAS in 2016. She earned her master's degree in English Language Studies Program, majoring in English Literature at the Postgraduate Program of the Faculty of Cultural Science

Her scholarly interest includes ecology and literature, children's literature, and Australian Literature. The focus of her master's research is the relationship between humans and nature in literature. Her first publication is entitled Understanding Nature Through language: Figurative Languages in Thiele's February Dragon, published in the International Journal of Innovative Science and Research Technology in February 2021.

Ms. Hikmah is looking forward to pursuing her Doctoral Program at the English language Studies, Postgraduate Program. 